\title{
カーボンナノチューブのコーティングによる導電繊維 [CNTEC」の開発と安全性に関する課題
}

Development and Risk Assessment of Electro-Conductive Fiber “CNTEC” by Carbon Nano-Tubes Coating 秋 庭 英 治

\section{初めに}

カーボンナノチューブ(CNT) は、1991 年に日本で発見 されて以来、その優れた機械的特性、導電性能、帯電防止 性能、電磁波・磁気遮蔽性能、熱安定性などの特性を活か すべく、様々な用途や製品への利用が試みられている。し かし、CNTは、カーボンナノチューブ間のファンデルワー ルスカによって凝集が生じ易く、それに伴ってカーボンナ ノチューブが集合した“ バンドル構造” (結束構造)を形成 してしまうため、カーボンナノチューブ本来のナノオー ダーのサイズメリットや、上記の優れた機械的特性、電気 伝導率、熱安定性などを十分に活かせないでいるのが実状 である。

当社は、茶久染色株式会社および松文産業株式会社と共 同で、北海道大学古月文志教授の指導の下に CNT 均一水 分散技術を応用して、CNT のコーティングによる導電繊 維「CNTEC(シーエヌテック)」の開発に成功した。本プ ロジェクトは、平成 $20 、 21$ 年度地域イノベーション創出 研究開発事業に採択されており、北海道大学、茶久染色、 松文産業、愛知産業技術研究所、クラレリビングの 5 団体 による産官学コンソーシアムとして進めている。本稿では、 この CNTネットワーク形成による新規導電繊維 $\lceil\mathrm{CNTEC} 」 の$ 製造方法、特徵および用途開発、そして安 全性に関する課題について紹介する。

\section{CNT 均一分散技術開発}

基本技術は、北海道大学大学院 地球環境科学研究院 総合化学部門環境修復分野の古月文志教授の開発による、 CNTの均一水分散技術である ${ }^{1,2)}$ 。

CNT は通常、凝集体として存在する。CNT の凝集はそ の表面原子が配位的に不飽和で有る為、隣接同士に配位し て、ファン・デル・ワールスカによる安定化エネルギーを 獲得する事によって起きる。本製造では分子内に正電荷及

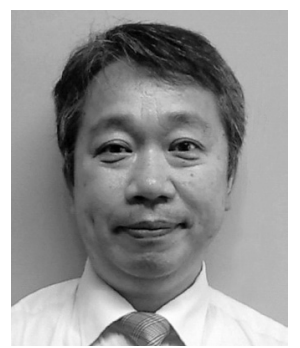

\section{EIJI AKIBA}

クラレリビング株) 研究開発部 部長

=530-8611 大阪市北区梅田 1-12-39

Tel :06-6348-9365 Fax:06-6348-9960 〈専門〉溶融紡糸、繊維加工

〈趣味〉山海の散策、グラフィックデザ イン
び負電荷を同時に持っている両性界面活性剤を分散剤とし て用いており、これがCNT 凝集体の表面で自己組織化し、 両性イオン分子膜を形成する。CNT凝集体を覆う両性イ オン分子膜は、双極子間の強い静電的相互作用によって、 他の CNT 凝集体を覆う両性イオン分子膜と静電的に結合 し、この結合力が $\mathrm{CNT}$ の凝集に打ち勝つことができる。 この方法は汎用のビーズミルで行う事ができ、特殊な装置 を必要としないため工業生産に適しているといえる。

この CNT 水分散液にバインダーを配合しコーティング 用原液とすることができる。この際、この両性界面活性剤 は、極性のあるバインダーの使用に対しても安定である為、 繊維素材別に接着性・耐久性の良好なバインダーの選択肢 も多くなるという利点もある。

\section{CNT 精密コーティング技術開発}

CNT コーティングによる導電糸の開発に際し、この導 電繊維を用いた繊維製品の取り扱い性、柔軟性、沉用性を 考慮し、ベースとなる繊維素材としてポリエステルマルチ フィラメントを採用した。この場合、構成する単糸全てに 均一で安定したCNT コーティングが必要となる。

マルチフィラメントへのコーティングにあたり、伝統的 な糸染色技術の一つである、糸プリント方式を基本とした 技術開発を進めてきた。ただし従来方式のままでは、バイ ンダー入りの CNT 分散液は、マルチフィラメントの表面 に付着するのみであり、糸束芯部にまで液を浸透させるこ とができなかった。これは、加工液の粘度が高くなるとさ らに困難になる。そこで、CNT 分散液と糸との接触時に、 その部分の糸に特定周波数の微細振動を与える事で、糸束 芯部への浸透性が上がり、さらに過剩に付与された分散液 が振り落とされる事で、糸表面に均一した塗膜を作成させ る手法を確立した。本手法により、剥離強度対策として有 効であるものの粘度の高く使用しづらい高強度のバイン ダーの使用も可能となった。(写真 1$)$

繊維の電気抵抗值は、繊維表面に付着し固化したバイン ダー中に含まれるCNTの量、つまり単位面積あたりの ネットワークを形成するCNT の量に比例する。CNT が 高濃度であるほど低い電気抵抗值となり、CNT 分散液の 濃度の設定によって、これを付与する繊維の電気抵抗值を 設定することができる。さらにその電気抵抗值は上記の均 一コーティング技術により、バラツキの少ない安定したも 
のとすることができる。また、バインダー定着のためには 乾燥・熱処理が必要であり、高温炉で一定時間熱を与え定 着させる高温キュアリングを行う事で、より強いバイン ダー固化皮膜を形成し、剥離などの耐摩擦脱落性、洗濯耐 久性の向上に繋げることができる ${ }^{3,4)}$

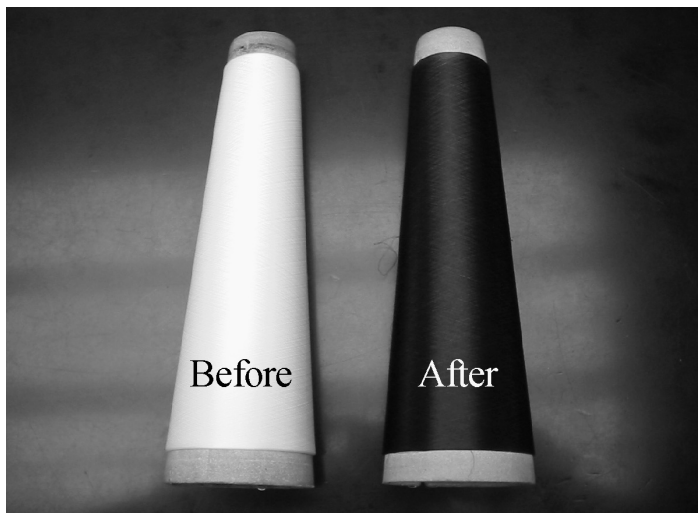

写真 1 糸プリントによる CNT コーティング糸

\section{3. 新規導電繊維の開発}

CNT の均一分散技術およびCNT の精密コーティング 技術により、種々の導電糸の開発を行ってきた。その幾つ かの事例を紹介する。

\section{1 帯電防止布帛用導電繊維}

一般的な導電繊維は導電カーボンを用いたものであり、 ポリマー練り込みによる溶融複合紡糸手法、あるいはモノ フィラメントへのコーティング手法によって生産されてい る。これらの手法では、導電カーボンはその導電層中に $10 \%$ を超える高濃度で導入する必要があり、製造上の制 約からその単糸繊度は $5 \mathrm{dtex}$ 以上と比較的太いのが現状で ある。また、導電繊維の電気抵抗值には適正值があり、高 すぎる場合には効率的な静電気の分散やコロナ放電を起こ しにくく、低すぎる場合には、該導電繊維に蓄積する電荷 量が大きくなりすぎ、再放電の際のエネルギー放出量が多 く好ましくない。適正な範囲は $10^{5} \sim 10^{10} \Omega / \mathrm{cm}$ とされてお り、特に $10^{5} \Omega / \mathrm{cm}$ 台の抵抗值が最適である。

我々は、ソフトな風合いと伸縮性を持つ導電繊維とする ために、24dtex-24fil の単糸繊度 1dtex のポリエステルマ

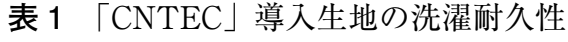

\begin{tabular}{|l|c|c|}
\hline 試験項目 & 原布 & 100 回洗濯後*** \\
\hline 表面漏洩抵抗值* $(\Omega)$ & $7.7 \times 10^{5}$ & $1.6 \times 10^{7}$ \\
\hline 摩擦帯電電荷量** $\left(\mu \mathrm{C} / \mathrm{m}^{2}\right)$ & 3.0 & 4.4 \\
\hline
\end{tabular}

*JIS L 1094-1997 参考法による＊*JIS L 1094-1997による ***JIS L 0217105 法による

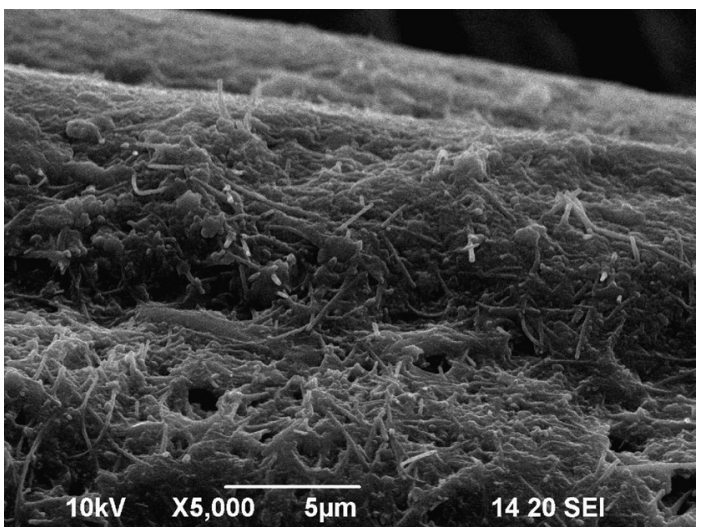

写真 $2\lceil C N T E C 」$ 単系表面写真

ルチフィラメント加工糸をベースとして用いた。目標とす る $10^{5} \Omega / \mathrm{cm}$ 線抵抗值は、安定した特定濃度の CNT 分散 液を用い、合わせて剥離に強いバインダーを用いることに より高耐久性の導電繊維を開発した。単系の表面には CNT を含む導電層が形成されており、糸長方向の安定した導電 性から良好な CNT ネットワークが形成されていることが わかる。(写真 2) 実際にこの導電繊維を 167Dtex ポリエ ステルマルチフィラメント加工糸と交撚し、167Dtex ベー スのッイル生地に $5 \mathrm{~mm}$ 間隔でグリッド状に組み込み、生 地の洗濯耐久性を評価した。生地は良好な表面抵抗值およ び摩擦帯電電荷量を示し、100 回洗濯後も維持しているこ とが判明した。JISの定める防爆仕様帯電防止布帛の摩擦 帯電電荷量の基準は $7.0 \mu \mathrm{C} / \mathrm{m}^{2}$ 以下であり、100 回洗濯後 もクリアしている。(表 1)

\section{$3.2\lceil$ 「゙クトラン」導電繊維}

ポリアリレート繊維の一つである、クラレの「ベクトラ ン」を使用し、我々の開発した CNT 精密コーティング技 術により導電繊維を開発した。繊維表面にCNT のネット ワークが良好に形成されており（写真 3 )、安定した $10^{4} \Omega /$
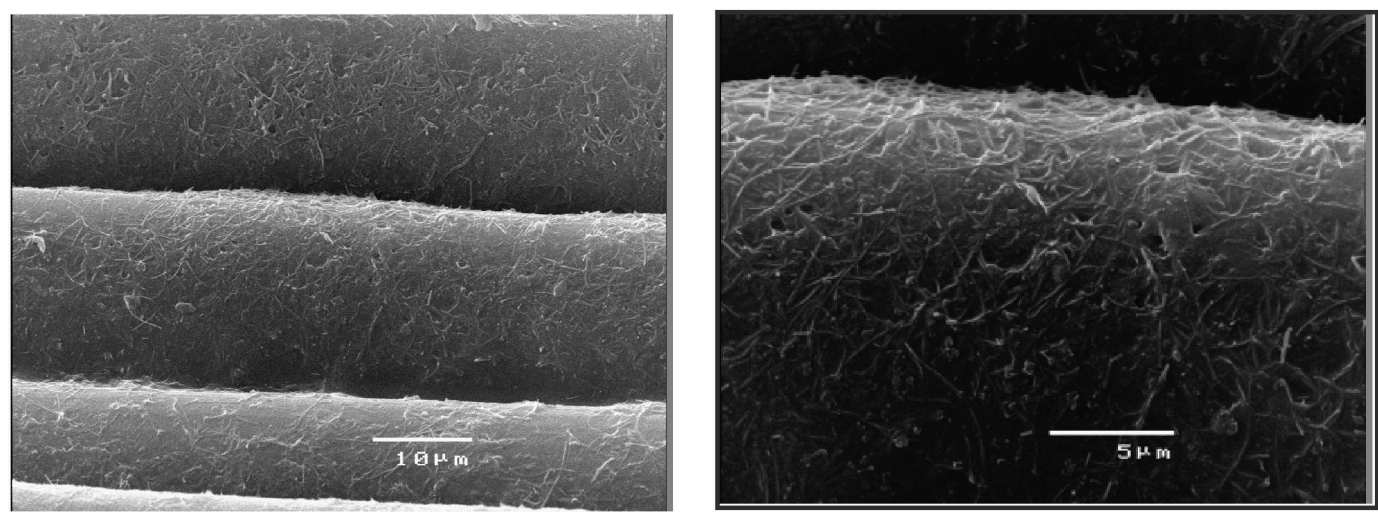

写真 3 CNT コーティングした「ベクトラン」導電糸 
表 2 CNT コーティングした「ベクトラン」導電糸の物性と摩擦堅牢度

\begin{tabular}{|c|c|c|c|c|}
\hline \multicolumn{2}{|c|}{ 銘柄 } & \multicolumn{2}{|c|}{ 「ベクトラン」(HT) } & \multirow{2}{*}{$\frac{1670 \mathrm{~T} / 300 \mathrm{f}}{24.0}$} \\
\hline \multirow{3}{*}{\multicolumn{2}{|c|}{ 物 }} & 破断強度 & $\mathrm{cN} /$ dtex & \\
\hline & & ヤング率 & $\mathrm{cN} /$ dtex & 485 \\
\hline & & 破断伸度 & $\%$ & 4.0 \\
\hline & 電 性 & 線抵抗值 & $\Omega / \mathrm{cm}$ & $1.4 \times 10^{4}$ \\
\hline \multirow{3}{*}{\multicolumn{2}{|c|}{ 摩擦耐久性 }} & 100 回 & $\Omega / \mathrm{cm}$ & $2.3 \times 10^{4}$ \\
\hline & & 200 回 & $\Omega / \mathrm{cm}$ & $2.9 \times 10^{4}$ \\
\hline & & 300 回 & $\Omega / \mathrm{cm}$ & $2.7 \times 10^{4}$ \\
\hline
\end{tabular}

$\mathrm{cm}$ 線抵抗值とともに、良好な摩擦耐久性を示している。 ポリアリレート纎維の導電纎維は前例がなく、今後の用途 開発が期待される。（表 2)

\section{4 非金属電線}

CNT 自体は金属なみの抵抗值を持ち、CNT が本来金属 なみの導電性を有することから、当初よりそのネットワー クにより金属電線の代替となる非金属電線を目指し、より 低い抵抗值を目指してコーティングの検討を行ってきた。 現在 $10^{3} \Omega / \mathrm{cm}$ のレベルながら、この導電糸を用いて、金 属センサー代替としての検討も行っている。武蔵工業大学 にて、筋肉埋め込み型慢性筋電電極として評価を行い、従 来屈曲により破断しやすかった金属線センサー代替として、 微弱な筋電をピックアップすることができることが判明し た。今後さらに低抵抗值を目指し、現行の金属電線と比較 して、軽量コンパクト、高い耐屈曲疲労性をメリットとす る非金属電線の開発を目指す。

\section{5 発熱布帛用導電繊維}

$10^{3} \Omega / \mathrm{cm}$ の線抵抗值を有するCNTECはこれ自体、通 電による発熱挙動を示す。この導電糸を緯系に配置し、経 糸をレギュラーポリエステル加工糸とした織物にて、緯糸 に電荷をかけることで生地全面が発熱する面状発熱体を開 発することができた。(写真 4) 到達温度は印加電圧と生地 の幅で調整ができ、軽量コンパクト、高い耐屈曲疲労性、 全面発熱性を特徵とする5)。

この生地を用いて、鉄道車両用材料燃焼試験をクリアす

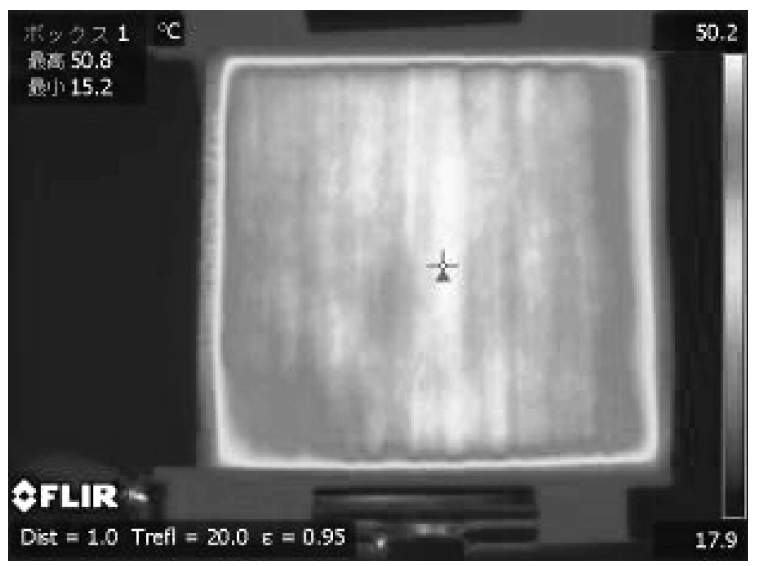

写真 4 全面均一発熱する面状発熱体
る面状発熱体を作成し、1月末〜 1 月半ばまでの期間、JR 北海道の流水ノロッコ号 (知床斜里〜網走)にて水タンクに 取り付け、凍結防止のモニター評価を実施した。最低気温 $-20^{\circ} \mathrm{C}$ の環境下、良好に凍結防止の効果を発揮すること ができた。

\section{CNT の安全性}

最近、CNT が中皮種を引き起こす懸念があると報道さ れ、CNT 原体を扱う研究現場や生産現場でのリスク管理、 またCNTを利用した商品のリスク管理が問題となってい る。現在、欧米を中心に国際的に急速に進行しており、実 際の暴露試験による危険性のデータも蓄積されている。 ISO でのナノ素材に関する健康・安全・環境に関する標準 化が進んでおり、OECDにても工業ナノ材料に関する作 業部会にて各国の情報を集約している。国内でも、ナノ素 材に関し、厚生労働省、経済産業省、環境省、内閣府も各々 検討会、研究会を発足している。産総研では、ナノ材料の 社会受容促進のための情報の利用および伝達のための研究 を行っており国内外情報の発信元として機能している。こ れらの情報に目ざとくあり、CNTの社会受容のレベルを 見極めながら、本研究の CNT 繊維製品を提案して行きた い。また、CNT 原体そのものでなく、CNT 付与製品から わずかに脱落する CNT 複合体のリスク評価についても、 検査機関による客観的なデー夕採取を行って行きたい。

\section{終わりに}

CNT の持つ様々な特性はネットワークを形成して初め て発揮され、そのためには CNT を単体均一分散させる技 術が必須である。我々は、CNT均一分散液を利用し、マ ルチフィラメントの単糸すべての表面への精密コーティン グによるCNT ネットワーク形成に成功し、CNT の導電 特性を 1 次元の繊維で再現することができた。今後さらに、 CNT 分散技術と精密コーティング技術により、CNT の持 つ導電性能を繊維で再現した CNTECを用いて、各種の 素材開発・用途開発を進めてゆく所存である。

\section{参考文献}

1）特開 2007-39623(P2007-39623A) カーボンナノチュー ブ分散ペースト、カーボンナノチューブ分散溶液およ びその製造方法 : 古月文志 
2) 「Disassembling Single-walled Carbon Nanotube Bundlesby Dipole/Dipole Electrostatic Interactions 」 Bunshi Fugetsu, Wenhai Han, Chemistry Letters Vol. 34 , No9, 1218(2005)

3）特願 2007-225966 カーボンナノチューブを付着した 合成繊維、合成繊維糸または繊維構造体およびそれら の製造方法：古月文志、秋庭英治
4）特願 2008-224821 カーボンナノチューブが付着した導 電性繊維、導電性系、繊維構造体およびそれらの製造 方法 : 古月文志、秋庭英治、蜂矢雅明

5) Carbon 47 (2009) 527-544 Bunshi Fugetsu, Eiji Akiba, Masaaki Hachiya, Morinobu Endo 